\title{
Photosynthetic Efficiency in Aroeira and Cedro After the Application of Salicylic Acid
}

\author{
Maria Eunice Lima Rocha ${ }^{1}$, Fernanda Ludmyla Barbosa de Souza ${ }^{1}$, João Alexandre Lopes Dranski ${ }^{1}$, \\ Mayra Taniely Ribeiro Abade ${ }^{1}$, Pablo Wenderson Ribeiro Coutinho ${ }^{1}$, Tatiane Priscila Chiapetti ${ }^{1}$, \\ Luanna Karoline Rinaldi ${ }^{2}$, Marlison Tavares Ávila ${ }^{1}$, Kildemir da Costa Milomes Junior ${ }^{1}$, Hannah Braz ${ }^{1}$, \\ Marlene de Matos Malavasi ${ }^{1} \&$ Ubirajara Contro Malavasi $^{1}$ \\ ${ }^{1}$ Universidade Estadual do Oeste do Paraná, Paraná, Brazil \\ ${ }^{2}$ Universidade Estadual de Maringá, Paraná, Brazil \\ Correspondence: Maria Eunice Lima Rocha, Universidade Estadual do Oeste do Paraná, Paraná, Brazil. E-mail: \\ eunice_agronomia@yahoo.com.br
}

Received: March 28, 2018

Accepted: August 17, 2018

Online Published: October 15, 2018

doi:10.5539/jas.v10n11p532

URL: https://doi.org/10.5539/jas.v10n11p532

\begin{abstract}
The objective of this research was to quantify the photosynthetic efficiency of Cedrela fissilis and Schinus terebinthifolius seedlings after application of salicylic acid for eight weeks. The experimental design was completely randomized, composed of four treatments, with five replicates of 20 seedlings each. The treatments consisted of increasing doses of the salicylic acid solution: $0,100,200,300 \mathrm{mg} \mathrm{L}^{-1}$. The solution was composed of salicylic acid, deionized water and adjuvant and applied with hand sprayer, weekly for 2 months. The parameters evaluated after the application of the acid consisted of the rate of $\mathrm{CO}_{2}$ assimilation, leaf transpiration, stomatal conductance and internal $\mathrm{CO}_{2}$ concentration, as well as water use efficiency, intrinsic water use efficiency and instantaneous carboxylation efficiency. In seedlings of Schinus terebinthifolius there was a reduction of the photosynthetic parameters and consequently a better use of water as the doses of the plant growth regulator were increased. In the seedlings of Cedrela fissilis the dose of $200 \mathrm{mg} \mathrm{L}^{-1}$ resulted in greater $\mathrm{CO}_{2}$ fixation per molecule of water lost and in this sense, it can be inferred that the increase in the doses of salicylic acid improved the photosynthetic efficiency, but the use of water was lower. Thus, for both species, lower doses are more recommended because there must be a balance between the fixed amount of $\mathrm{CO}_{2}$, the plant generated from photoassimilates and the amount of water lost, in order not to generate a negative potential in the plant metabolism.
\end{abstract}

Keywords: defense, native, photosynthetic efficiency

\section{Introduction}

The use of native wood species adds great commercial and social value to the environment in which they are inserted. In this sense, it is of great interest to increase the production of large scale and better quality seedlings. Thus, studies focusing on the potential, uses, establishment, development, practices and management in the nursery and in the field should be developed (Gonçalves et al., 2012).

The Schinus terebinthifolius Raddi. is a native tree, not endemic to Brazil belonging to the family of Anacardiaceae. Among the characteristics of the species, it is considerd a pioneer species with rusticity and great phenotypic plasticity, and therefore has great potential of use in programs of environmental reforestation and revegetation of degraded areas (Carvalho et al., 2013).

Aroeira is used for fodder of bees and goats, as raw material for fences and as an ornamental plant, as well as cosmetic, food and habitat restoration (Carvalho et al., 2015; Nickerson \& Flory, 2015).

In addition, there are reports that the species also has a larvicidal, insecticidal, antidepressant, hepatoprotective and photoprotective effect (Abdou et al., 2015; Bulla et al., 2015; Piccinelli et al., 2015).

Cedrela fissilis Vellozo is a native tree species which can reach from 20 to $35 \mathrm{~m}$ in height and a diameter of 60 to $90 \mathrm{~cm}$ widely used for reforestation programs. The species is described as deciduous and occurs generally in moist, deep, and well drained soils (Caires et al., 2011). Cedar is found from the Amazon to the Atlantic Forest, present in both primary forest and secondary forests, but its occurrence is higher between Rio Grande do Sul and 
Minas Gerais (Biernaski et al., 2012). Studies have highlighted the potential of the species for remediation of soils contaminated by heavy metals (Sakuragui et al., 2013).

Due to the quality of its wood, cedar has been progressively explored in places of occurrence and for this reason, for several years, it has been listed as a threatened species deserving preservation (Santos et al., 2009).

Plants have substances which manifested in response to the most diverse stressors resulting in physiological, morphological, biochemical, cellular and even molecular changes. Some of these compounds, known as plant hormones, will act as flags, affecting plant development and growth (Lopez et al., 2008).

Knowing the dynamics of growth regulators is extremely important, since it can contribute to the management of forests and the quality of the final product, as these will act directly in the formation of wood and in the attenuation of biological or non-biological stresses (Pereira et al., 2011; Asgher et al., 2015).

Recent research has given great importance to the endogenous application of salicylic acid in order to act in the development, growth and establishment of the seedlings in the field, besides promoting greater resistance to possible environment stresses.

Salicylic acid (SA) is an endogenous growth regulator, considered a signaling molecule, belonging to the group of phenolic compounds. The molecule consists of a hydroxyl group attached to an aromatic ring and participates in several biological processes of the plants, activating metabolic routes linked to plant defense (Hayat et al., 2010; Khan et al., 2010).

Some benefits can be observed when exogenous application of SA. Among those, an increase in germination, in growth and development of plants and an increase in the content of photosynthetic pigments (Hayat et al., 2010; Kabiri et al., 2012; Kang et al., 2014). In addition, recent studies have highlighted the potential of salicylic acid as an important regulator of photosynthetic activities, acting on photosystem I (PSII), photosynthetic pigments and the activity of enzymes linked to the primary and secondary metabolism of plants, such as rubisco and anidrase (Noriega et al., 2012; Zhang et al., 2015).

The concentration of these compounds in the plant can be influenced by many factors such as soil conditions, climate and plant development. The objective of this research was to quantify photosynthetic efficiency of Cedrela fissilis and Schinus terebinthifolius seedlings after application of SA for 8 weeks.

\section{Material and Methods}

The research was conducted in the western region of the State of Paraná, latitude $24^{\circ} 33^{\prime} 24^{\prime \prime}$ S, longitude $54^{\circ} 05^{\prime} 67^{\prime \prime} \mathrm{W}$ and altitude of $420 \mathrm{~m}$. According to IAPAR and the classification of Koppen, the climate of the region is Cfa subtropical, maintaining the average annual temperature between 22 and $23{ }^{\circ} \mathrm{C}$, with rains well distributed during the year and hot summers (Caviglione et al., 2001). Relative humidity and air temperature during the application of the treatments (Figure 1) were obtained with a data logger (Klima Logg Smart Model).

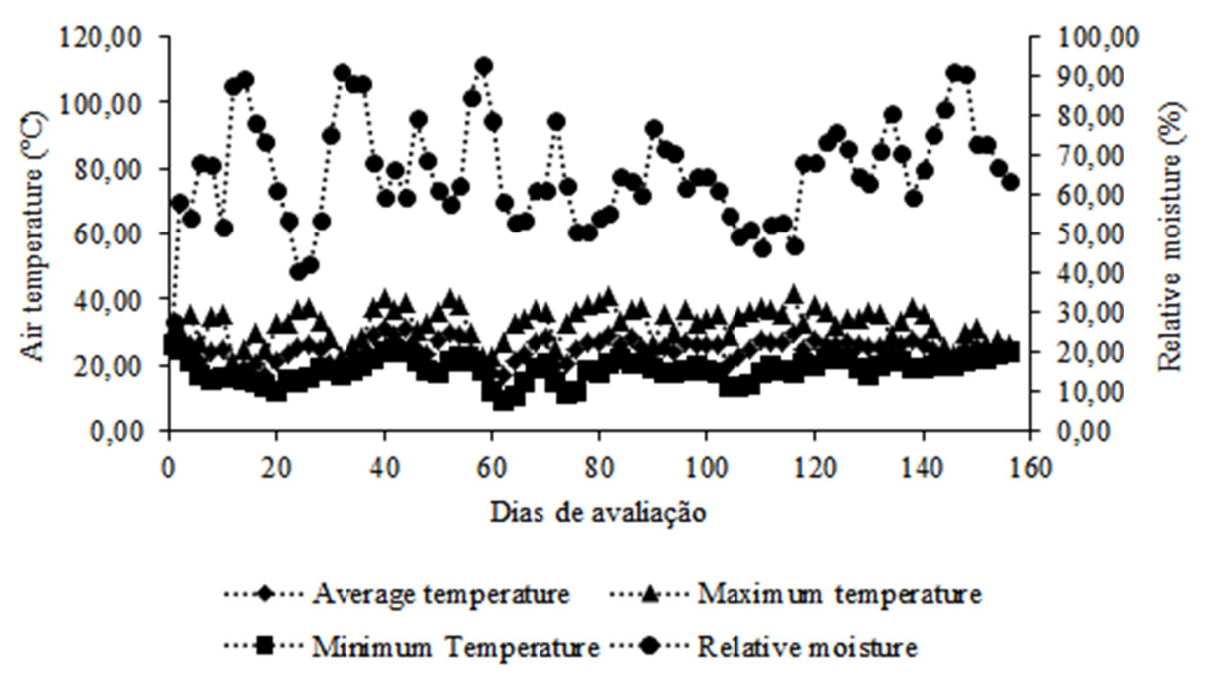

Figure 1. Minimum, average and maximum values of the temperature and average of the relative humidity of the air during the experiment with cedar and aroeira in greenhouse 
We used 400 seedlings of Schinus terebinthifolius (aroeira) and 400 seedlings of Cedrela fissilis (Cedro) obtained from Itaipu Binacional and the Environmental Institute of Paraná (EIP). The three month seedlings were propagated in $120 \mathrm{~cm}^{3}$ plugs filled with a mixture of local soil and humus (NITOSOLO RED Eutroferric of very clayey texture), in a ratio of $3: 1$.

Prior to the treatments, seedlings underwent acclimatization in a protected shadehouse for approximately 30 days between August and September. During that period, the seedlings were fertilized with $3 \mathrm{~mL}$ of nutrient solution in order to provide macro and micronutrients required in the growing phase (Table 1).

Table 1. Composition of the nutritive solution for seedling fertilization

\begin{tabular}{lccccc}
\hline \multicolumn{5}{c}{ Nutritive solution } \\
\hline $\mathrm{KH}_{2} \mathrm{PO}_{4}$ & $\mathrm{MgSO}_{4}$ & $\mathrm{KNO}_{3}$ & $\mathrm{Ca}\left(\mathrm{NO}_{3}\right)_{2} 4 \mathrm{H}_{2} \mathrm{O}$ & Micronutrients complete & Fe-EDTA \\
\hline$-0-0-0$ & 2.0 & 5.0 & 5.0 & 1.0 & 1.0 \\
\hline 1.0 & 2.0 & & \\
\hline
\end{tabular}

Seedlings were measured (height, diameter and number of leaves) before treatments. Aroeira seedlings showed averages $(\mathrm{n}=400)$ of $14.60 \mathrm{~cm}$ height, $2.99 \mathrm{~mm}$ diameter and 13.34 leaves whereas for cedar seedlings $(\mathrm{n}=400)$ showed averages of 8.09 height, $2.51 \mathrm{~mm}$ diameter and 6.62 leaves.

The experimental design was a completely randomized composed of 4 treatments, 5 replicates with 20 seedlings in each, totaling 400 experimental units (seedlings) for each species. The treatments consisted of increasing doses of SA:

- T1: $100 \mathrm{mg} \mathrm{L}^{-1}$ of salicylic acid;

- T2: $100 \mathrm{mg} \mathrm{L}^{-1}$ of salicylic acid;

- T3: $200 \mathrm{mg} \mathrm{L}^{-1}$ of salicylic acid;

- T4: $300 \mathrm{mg} \mathrm{L}^{-1}$ of salicylic acid.

Treatments wer applied weekly for 2 months from September 26 until November 14. The solution consisted of SA, deionized water and adjuvant (Agral $\left.{ }^{\circledR}\right), 30 \mathrm{~mL}$ to $100 \mathrm{~L}^{-1}$ of water. We used a hand sprayer between 6 and 8 am. Irrigation consisted of three shifts of 15 minutes each in addition to weeding.

Measurement included photosynthetic potential, measured by gas exchange, $\mathrm{CO}_{2}$ assimilation rate (A), leaf transpiration (E), stomatal conductance $\left(\mathrm{g}_{\mathrm{s}}\right)$ and internal $\mathrm{CO}_{2}$ concentration $(\mathrm{Ci})$ in leaves fully expanded and photosynthetically active using a IRGA (Li-6400 XT). Measurements were carried out on cloudy days from 9 to $11 \mathrm{a} . \mathrm{m}$, in order to obtain greater uniformity in relation to the climatic conditions for the analyzes. With artificial saturated light of $1,200 \mu \mathrm{mol} \mathrm{m} \mathrm{m}^{-2} \mathrm{~s}^{-1}$ and $\mathrm{CO}_{2}$ concentration at $380 \mu \mathrm{mol}$, under a constant temperature of $25^{\circ} \mathrm{C}$.

At the end of the test, the chlorophyll content was determined by the Arnon method (1949), in leaves located in the middle third of the plants (photosynthetically active), $14.0 \mathrm{~cm}^{2}$ of leaf area were removed and packed in Falcon tubes of $15.0 \mathrm{~cm}^{3}$ precoated with foil and filled with $10 \mathrm{ml}$ of $80 \%$ acetone. The samples were incubated at $25^{\circ} \mathrm{C}$ for $48 \mathrm{~h}$.

$$
\begin{gathered}
\text { Chlorophyll } a=12.7 \mathrm{~A}_{663}-2.69 \mathrm{~A}_{645} \\
\text { Chlorophyll } b=22.9 \mathrm{~A}_{645}-4.68 \mathrm{~A}_{663} \\
\text { Total Chlorophyll = Chlorophyll } a+\text { Chlorophyll } b
\end{gathered}
$$

The results were submitted to the Bartlett and Shapiro-Wilk tests in order to test the homogeneity and normality followed by the analysis of variance. When appropriated we tested treatment means using Dunnett test and comparison between SA doses the control treatment $\left(0 \mathrm{mg} \mathrm{L}^{-1}\right)$.

\section{Results and Discussion}

SA may induce morphological, biochemical or physiological alterations such as the increase in the content of photosynthetic pigments under normal or stressful conditions in plants (Singh \& Usha, 2003; Khodary, 2004). Several studies have demonstrated the importance of exogenous application of SA to various metabolic functions in plants, whether physiological, ecological or biochemical. These responses have not been fully clarified, mainly because both the characteristics of the species and the climatic factors can influence the responses to the use of this inducer (Pál et al., 2014). 
Results from seedlings of $S$. terebinthifolius did not show difference $(\mathrm{P}>0.05)$ with application of SA for chlorophyll a, b and total. On the other hand, seedling of $C$. fissilis treatments 1 and 4 did not differ from each other, but differed from treatments 2 and 3, which showed a reduction in chloroplastidic pigments (Figure 2).

At the $300 \mathrm{mg} \mathrm{L}^{-1}$ dose of SA, the existing reduction was lower than detected from the other treatments. This treatment did not vary from the control seedlings because the responses to exogenous application of the growth regulator may vary according to the dose, time of application, physiology and age of the vegetables, besides varying according to the species and time of exposure to the inducer (Picolotto et al., 2009).

Chlorophyll $\mathrm{b}$ in seedlings of $C$. fissilis, was not influenced by $(\mathrm{P}>0.05)$ with the increase in SA doses.

In $C$. fissilis seedlings there was a decrease in the concentration of total chlorophylls resulting by reduction of the number of leaves.

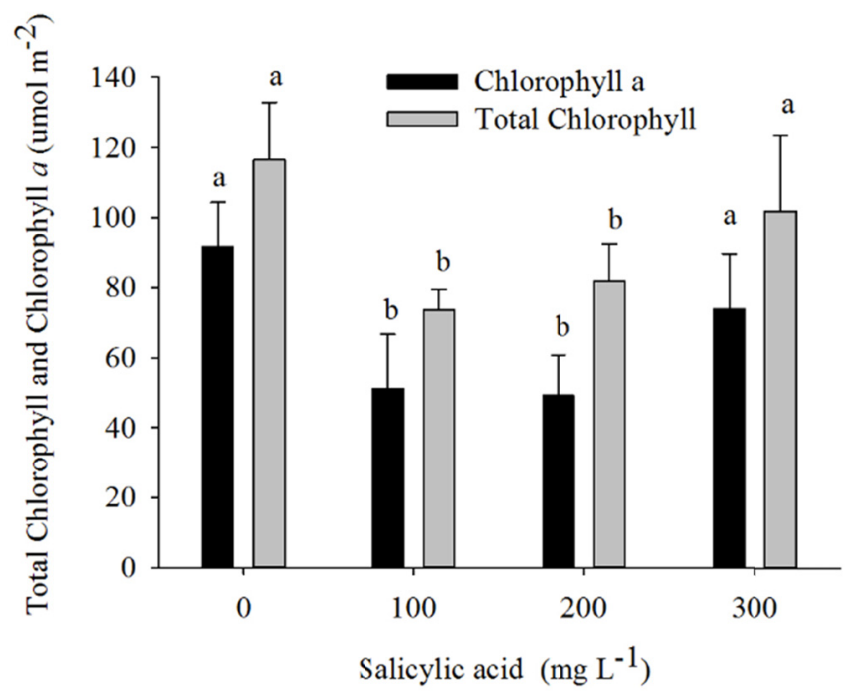

Figure 2. Chlorophyll a and total chlorophyll content in Cedrela fissilis seedlings after application of salicylic acid

Note. The averages followed by the same letter do not differ statistically from each other by the Dunnett test at the $5 \%$ probability level.

Measurement of net $\mathrm{CO}_{2}$ assimilation showed a significant difference $(\mathrm{P}>0.05)$ as SA doses increased in seedlings of both species. Mean values of the treatments were equal to $5.54 \mu \mathrm{mol} \mathrm{m}^{-2} \mathrm{~s}^{-1}$ in C. fissilis seedlings and for S. terebinthifolius the averages ranged from 4.07 to $4.49 \mu \mathrm{mol} \mathrm{m}^{-2} \mathrm{~s}^{-1}$. Similar results were obtained by Mazzuchelli, Souza and Pacheco. (2014) where the application of salicylic acid did not result in significant statistical difference $(\mathrm{P}>0.05)$ for the photosynthetic determinations in Eucalyptus urophylla $\mathrm{x}$ Eucalyptus grandis (clone H13) plants submitted to irrigation regimes.

Temperatures between 30 and $35{ }^{\circ} \mathrm{C}$ can promote inhibition of $\mathrm{CO}_{2}$ assimilation in $\mathrm{C}_{3}$ plants and impair activation of Rubisco, inhibiting the enzyme linked to its conversion (Rubisco activase), resulting in stomatal closure and reduction of photosynthetic activity (Oliveira et al., 2005).

The internal $\mathrm{CO}_{2}$ concentration is an important parameter, since it allows direct evaluation of plant productivity from the determination of intercepted solar energy and the amount of $\mathrm{CO}_{2}$ in non-stressing edapho climatic conditions, high $\mathrm{CO}_{2}$ content will result in high rates of photosynthesis (Taiz \& Zeiger, 2017).

In $S$. terebinthifolius seedlings, the internal $\mathrm{CO}_{2}$ concentration did not show difference $(\mathrm{P}>0.05)$ between treatments 1,2 and 3. With the dose of $300 \mathrm{mg} \mathrm{L}^{-1}$, however, the lowest mean was observed, equivalent to $254.46 \mu \mathrm{mol} \mathrm{m}^{-2} \mathrm{~s}^{-1}$ (Figure 3).

The $\mathrm{Ci}$ presented reduction in seedlings submitted to the control treatment for the maximum dose of SA. This is related to the stomatal conductance, which was also lower in this treatment. Thus, the lower the conductance the lower the flow of gases, water and luminosity that flow through the stomata. 
The lower the gas exchange between plants and the lower atmosphere the assimilation of $\mathrm{CO}_{2}$ and the less the conversion of light energy into photoassimilates, causing the plant to have fewer reserves and become more susceptible to adverse conditions.

SA is required in small amounts to activate or inhibit routes in plant metabolism. High doses of SA can affect photosynthesis, osmotic adjustment and antioxidant metabolism, not promoting tolerance in plants, on the contrary, triggering a high level of stress in the plants (Hayat et al., 2010). In this sense, S. terebinthifolius seedlings responded negatively to the maximum dose of SA demonstrating that excess chemical stimulation could impair essential plant activities (Figure 3). The reduction of the maximum value obtained with $100 \mathrm{mg} \mathrm{L}^{-1}$ compared to $300 \mathrm{mg} \mathrm{L}-1$ was $15.75 \%$ in the internal $\mathrm{CO}_{2}$ concentration.

In controversy Nivedithadevi et al. (2012) reinforced that the use of SA at appropriate concentrations may improve photosynthetic rate and consequently the growth and productivity of the species, but the results will vary according to the intrinsic and extrinsic conditions of the species.

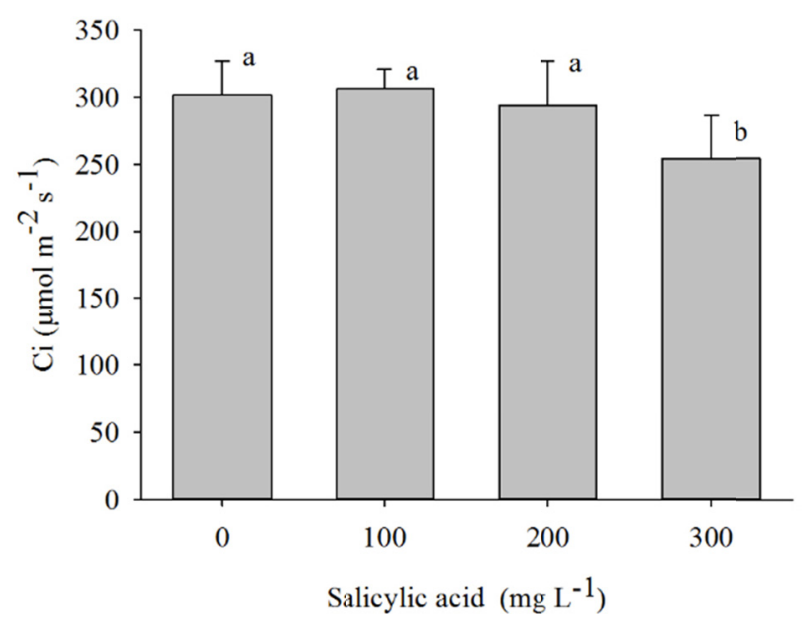

Figure 3. Internal concentration of $\mathrm{CO}_{2}(\mathrm{Ci})$ in seedlings of Schinus terebinthifolius after application of salicylic acid

Note. The averages followed by the same letter do not differ statistically from each other by the Dunnett test at the $5 \%$ probability level.

In C. fissilis seedlings the internal $\mathrm{CO}_{2}$ concentration were not affected $(\mathrm{P}>0.05)$ by $\mathrm{SA}$ and the averages ranged from 212.63 to $288.45 \mu \mathrm{mol} \mathrm{m}^{-2} \mathrm{~s}^{-1}$.

Responses to exogenous application of SA will not always be noticeable, since the effect is dependent on the stage of development of the plants, applied amount of the hormone, concentration, mode of application, edaphic and climatic conditions, besides factors related to physiology and morphology of the seedlings (Horváth et al., 2007).

The rate of assimilation and the concentration of $\mathrm{CO}_{2}$ are correlated variables, since the higher $\mathrm{CO}_{2}$ concentration in the leaves is the result of the greater assimilation in the plants, but if any structure or physiological activity is impaired, this will trigger a series of problems (Jadoski et al., 2005). In this research, for example, stomatal conductivity was low, which could result in low assimilation and carbon sequestration, lower energy production, ceasing of essential plant activities, leading to the death of cells and plants. Therefore, it is interesting that salicylic acid acts in these processes, conferring tolerance to the vegetables under stressful conditions.

When analyzing the instantaneous efficiency of carboxylation in seedlings of $S$. terebinthifolius and $C$. fissilis there was no influence $(\mathrm{P}>0.05)$ from doses of SA and the average across treatments was 0.021 and 0.018 , respectively.

High concentrations of SA may negatively affect the physiology of seedlings, promoting the decrease of carbon fixation as a consequence of Rubisco inhibition. As a result, the main activities of the plants can be impaired due to the interruption in the Calvin cycle, mainly the photosynthesis and respiration of the plants. 
The instantaneous efficiency of carboxylation depends directly on the availability of $\mathrm{CO}_{2}$ present inside the leaves, amount of radiation, temperature and enzymatic activity, so when these factors are affected the carboxylation efficiency is impaired, leading to the paralysis of activities essential for the normal functioning of the vegetable.

Moreover, if the amount of $\mathrm{CO}_{2}$ is low, it will hinder the entry of this gas into the cells, affecting the carbon input and energy production, interrupting the entire vegetative cycle of plants (Taiz \& Zeiger, 2017).

Seedlings when exposed to some nursery practices alter their physiological characteristics. Among those, the photosynthetic rates, which, in general, are low due to the low stomatal conductance when the stress conditions are exposed. Thefore, practice can alter the perspiration, promoting the reduction of the same and promoting the osmotic regulation of the cells.

In seedlings of S. terebinthifolius, stomatal conductance was reduced with increased doses of SA. For the dose of $300 \mathrm{mg} \mathrm{L}^{-1}$, the average stomatal conductance was $0.05 \mu \mathrm{mol} \mathrm{m}^{-2} \mathrm{~s}^{-1}$, which may have occurred because at the maximum dose there was a lower flow of water and gases in the stomata (Figure 4). With the decrease of the conductivity there is less contribution and transport of energy from the environment to the cells, interrupting the flow soil-plant and atmosphere. This interaction is complex because it depends on the environmental variables, the characteristics of the species and the growth inducer. Additionally, depending on those conditions, the application of exogenous hormonal sources can bring some harm to the general metabolism of plants. Melotto et al. (2006) reported that $0.4 \mathrm{mM}$ of SA induced stomatal closure and reduced stoma media mediated by stomata in Arabidopsis thaliana.

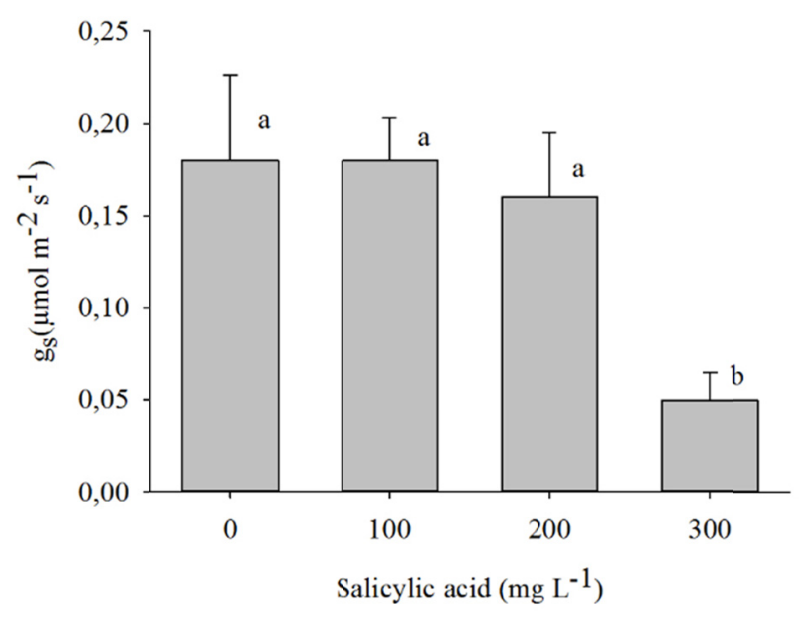

Figure 4. Stomatal conductance ( $\mathrm{g}_{\mathrm{s}}$ ) in seedlings of Schinus terebinthifolius after application of salicylic acid

Note. The averages followed by the same letter do not differ statistically from each other by the Dunnett test at the $5 \%$ probability level.

In addition to this justification, factors such as temperature and humidity may have influenced this response in the seedlings. Situations of light or water stress may have been signaled the root to produce abscisic acid and promote stomatal closure, thus reducing water flow and $\mathrm{CO}_{2}$.

As can be observed in Figure 1, there was great oscillation of air temperature and relative air humidity in the months when the seedlings were in the field, mainly in the final phase, where the quantification of gas exchanges (between 140 and 160 days). The humidity reached approximately $91 \%$ and the maximum and minimum temperature ranged from 17.3 to $37.4{ }^{\circ} \mathrm{C}$, which may justify the physiological changes observed in both species.

According to Oliveira et al. (2002), as the stomatal conductance is a point measure and will determine the number of stomata that are open at the time of reading. If the plant is exposed to a momentary stress situation the response will present a reduction, agreeing with the results obtained in research.

In seedlings of $C$. fissilis the stomatal conductance did not vary according to the application of SA and the average reading was $0.097 \mu \mathrm{mol} \mathrm{m} \mathrm{m}^{-2} \mathrm{~s}^{-1}$. 
The plants present different responses even when exposed to the same conditions. So it is interesting to highlight these characteristics and to study in detail what changes, whether these are morphological, physiological or biochemical or even characteristics of the environment that will affect the growth and survival of the seedlings, both initially development phases.

Studies have highlighted the potential of hormones such as auxin, cytokinins, ethylene, brassinosteroids, jasmonate and, more recently, salicylic acid in stomatal regulation (Haubrick et al., 2006).

Under stress conditions, the stomata, which are pores of the epidermis, can be affected and thus activate responses in the plants, promoting the increase of AS, this in turn, along with other hormones may promote stomatal closure.

These responses may be reflected in the generation of reactive oxygen species and accumulation of calcium and hydroxyl, neutralizing the environment and stimulating the closure of the pores of plants (Melotto et al., 2006; Khokon et al., 2011).

Inversely proportional to the use of water, transpiration was reduced in S. terebinthifolius seedlings and the means were $3.15 ; 3.14 ; 3.01$ and $1.57 \mu \mathrm{mol} \mathrm{m} \mathrm{m}^{-2} \mathrm{~s}^{-1}$ with increasing doses of SA and reduction of treatment 1 to 4 was $50.16 \%$ (Figure 5 ).

Both carbon assimilation and transpiration occurs preferentially by the stomatal route. In $S$. terebinthifolius the $\mathrm{CO}_{2}$ contribution decreased when SA doses increased due to the stomatal closure (less stomatal conductance) and seedlings lost less water in the form of vapor, reduced the acquisition of photoassimilates, but presented a better use of water.

Marenco et al. (2014) pointed out that the water potential of the leaf does not remain constant throughout the day. This occurs basically, because leaf transpiration is different from the rate of absorption by the roots, generating electrochemical potential gradient. Therefore, there is a water movement from the root system to the aerial tissues promoting the continuous soil-plant-atmosphere. The same authors further argued that sap flow will increase during the first hours of the day because of irradiance and the stomata will open up, increasing stomatal conductance and increasing transpiration.

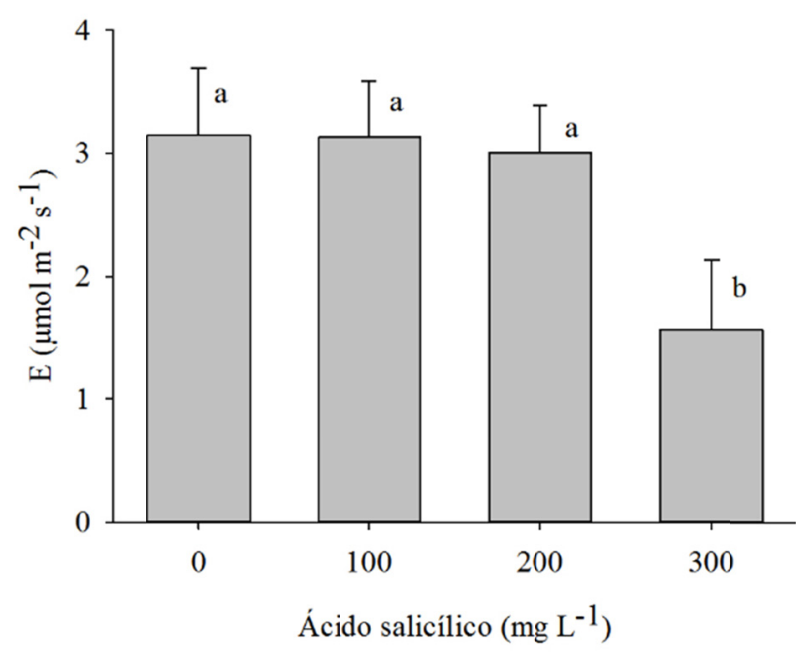

Figure 5. Transpiration (E) in seedlings of Schinus terebinthifolius after application of salicylic acid

Note. The averages followed by the same letter do not differ statistically from each other by the Dunnett test at the $5 \%$ probability level.

On the other hand, seedlings of $C$. fissilis did not show a difference $(\mathrm{P}>0.05)$ for transpiration after application of SA with values ranging from 2.28 to $3.03 \mu \mathrm{mol} \mathrm{m} \mathrm{m}^{-2} \mathrm{~s}^{-1}$.

Values (Figure 6) of water use efficiency in S. terebinthifolius seedlings submitted to treatments 2 (1.74) and 3 (2.75) were statistically similar to the control treatment (2.01) but differed from seedlings that received the maximum tested dose of the regulator (3.34). With increased doses of SA there was a better use of water by seedlings, revealing that SA may have favored and improved metabolic activities associated with water use. 
Under field conditions, this characteristic can be very important, since it may reduce seedling and decrease the loss of water, attenuating post-planting shock (Jacobs \& Landis, 2009).

The greatest use of water was obtained with the dose of $300 \mathrm{mg} \mathrm{L}^{-1}$ due to the lower transpiration. However, at the same dose, there was smaller stomatal conductance and consequently photosynthesis.

In summary, the photosynthetic efficiency also decreases and although the seedling is losing less water, it is also producing fewer photoassimilates and consequently reducing plant biomass.

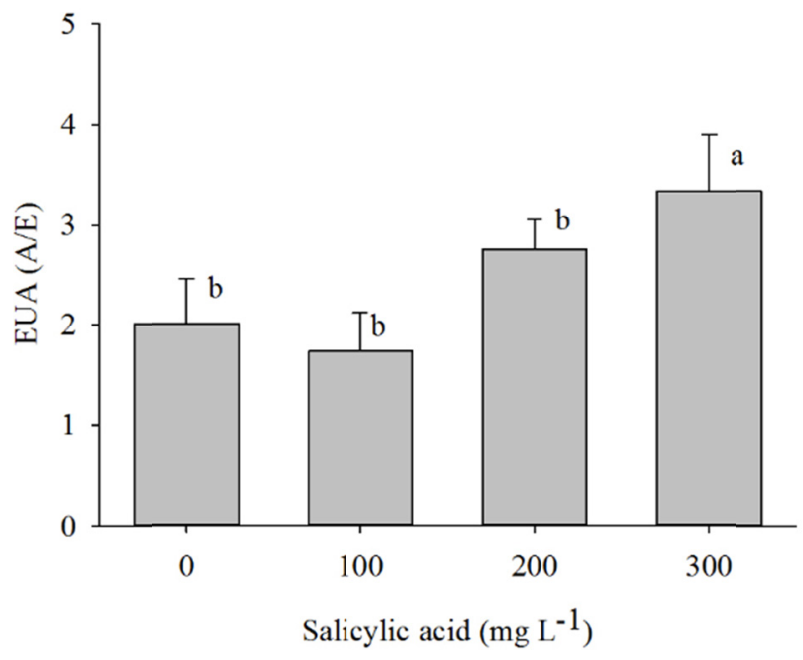

Figure 6. Efficiency of water use (EUA) on seedlings of Schinus terebinthifolius after application of salicylic acid

Note. The averages followed by the same letter do not differ statistically from each other by the Dunnett test at the $5 \%$ probability level.

The efficiency of water use in C. fissilis seedlings showed no difference $(\mathrm{P}>0.05)$ with the application of SA. In adverse situations, seedlings may present changes in their photosynthetic activities, such as stomatal conductance, transpiration and the efficiency of water use, but this is dependent upon factors linked to the species or the environment (Ferraz et al., 2012).

Scalon et al. (2011) with Guazuma ulmifolia Lam. seedlings reported that the water use efficiency did not show difference $(\mathrm{P}>0.05)$ when exposed to the water stress condition. It should be emphasized that those variables are dependent on internal and external factors of the plants, so, in a certain condition they will express different responses.

With seedlings of $S$. terebinthifolius subjected to SA the intrinsic efficiency of water use resulted in differences $(\mathrm{P}<0.05)$ only for the treatment equivalent to the $300 \mathrm{mg} \mathrm{L}^{-1}$ with a value of 84.68 (Figure 7).

The relationship between photosynthesis and transpiration indicates the instantaneous efficiency of water use, demonstrating the amount of carbon the plant attaches to each molecule of water lost (Jaimez et al., 2005).

Thus, when there was an efficient use of water, there was a reduction in the internal concentration of $\mathrm{CO}_{2}$ and its assimilation, demonstrating that the dose may not be adequate when assessing all the physiological characteristics. 

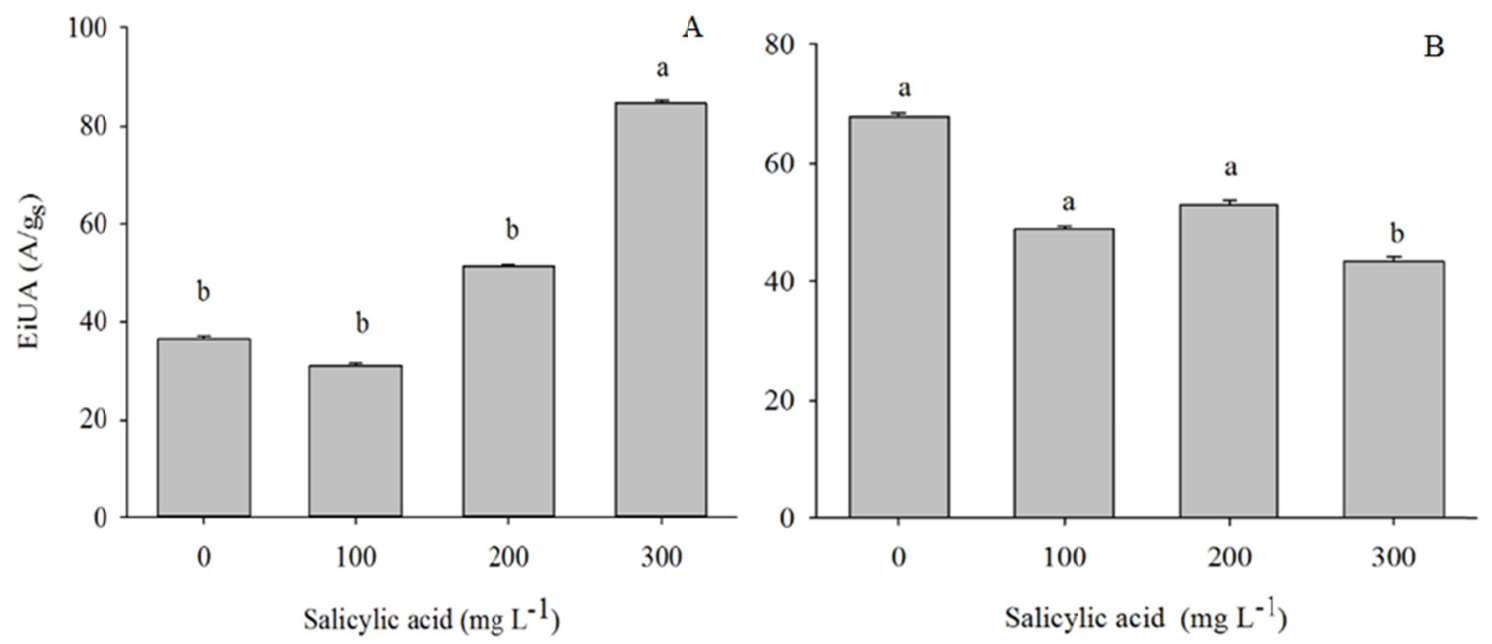

Figure 7. Intrinsic water use efficiency (EiUA) in seedlings of Schinus terebinthifolius (A) and Cedrela fissilis (B) after application of salicylic acid

Note. The averages followed by the same letter do not differ statistically from each other by the Dunnett test at the $5 \%$ probability level.

The intrinsic water use efficiency use in Cedrela fissilis seedlings after application of $300 \mathrm{mg} \mathrm{L}^{-1}$ of AS resulted in the lowest mean, equal to 43.27 that differed statistically from the other treatments (Figure 7).

Plant hormones are required in small amounts and the excess can generate numerous stresses on plants, altering physiological, biochemical and morphological activities, as well as stimulating the production of secondary metabolites.

In addition, terrestrial plants have specific signs that can interrupt some metabolic activities under adverse conditions in order to reduce energy expenditure by redirecting them to produce protective substances.

Thus, the parameters studied are very important when choosing the most appropriate species for each purpose and environment, since they are important indicators of the development of the plants under specific conditions.

\section{Conclusion}

Seedlings of S. terebinthifolius receiving SA for eight weeks resulted in a reduction in internal $\mathrm{CO}_{2}$ concentration, stomatal conductance and transpiration, but increased water use efficiency and the intrinsic efficiency of water use, demonstrating that the doses tested favored the use of water, but reduced assimilation and production of $\mathrm{CO}_{2}$ and, consequently, the contribution of photoassimilates.

However, it is interesting to note that photosynthetic reduction is a strategy of the terrestrial plants to avoid stressful conditions and may be advantageous provided that this situation occurs quickly, not significantly affecting the normal metabolism of the plants.

The maximum tested dose of the plant regulator induced stress in seedlings and therefore there was a reduction of the photosynthetic parameters, which may have contributed to the increase of resistance.

In seedlings of $C$. fissilis there was a reduction in the intrinsic efficiency of water use and the dose of $200 \mathrm{mg} \mathrm{L}^{-1}$ reflected in the greater loss of water and higher carbon fixation. Chlorophyll a and total contents decreased as the SA doses increased, but the $300 \mathrm{mg} \mathrm{L}^{-1}$ dose did not differ from the control seedlings. Different from results obtained with $S$. terebinthifolius seedlings, the dose of $200 \mathrm{mg} \mathrm{L}^{-1}$ resulted in greater $\mathrm{CO}_{2}$ fixation per molecule of water lost. Therefore, it can be inferred that the increase in the doses of salicylic acid improved the photosynthetic efficiency.

For seedlings of both species lower doses of SA are more recommended in order not to generate a negative potential in the plant metabolism.

\section{References}

Abdou, R. H., Saleh, S. Y., \& Khalil, W. F. (2015). Toxicological and biochemical studies on Schinus terebinthifolius concerning its curative and hepatoprotective effects against carbon tetrachloride-induced liver injury. Pharmacognosy Magazine, 11(42), 93-101. https://doi.org/10.4103/0973-1296.157705 
Arnon, D. I. (1949). Copper enzimas in isolated cloroplasts Polyphenoloxidase in Beta vulgaris. Plant Physiology, 24(1), 1-15. https://doi.org/10.1104/pp.24.1.1

Asgher, M., Khan, M. I. R., Anjum, N. A., \& Khan, N. A. (2015). Minimizing toxicity of cadmium in plants-role of plant growth regulators. Protoplasma, 252(2), 399-413. https://doi.org/10.1007/s00709-014-0710-4

Biernaski, F. A., Higa, A. R., \& Silva, L. D. (2012). Genetic variability for juvenile characters of Cedrela fissilis Vell. Progenies: A subsidy for definition of seed collection zone. Revista Árvore, 36(1), 49-58. https://doi.org/10.1590/S0100-67622012000100006

Bulla, M. K., Hernandes L., Baesso, M. L., Nogueira, A. C., Bento, A. C., Bortoluzzi, B. B., ... Cortez, D. A. (2015). Evaluation of Photoprotective Potential and Percutaneous Penetration by Photoacoustic Spectroscopy of the Schinus terebinthifolius Raddi Extract. Photochemistry and Photobiology, 91(3), 558-566. https://doi.org/10.1111/php.12419

Carvalho, M. G., Melo, A. G. N., Aragão, C. F. S., Raffin, F. N., \& Moura, T. F. A. L. (2013). Schinus terebinthifolius Raddi: Composição química, propriedades biológicas e toxicidade. Revista brasileira de plantas medicinais, 15(1), 158-169.

Carvalho, R. O., Machado, M. B., Lopes, R. S., Scherer, V. S., Cruz, W. A., Luz, M. L. G. S., ... Gomes, M. C. (2015). Agroindustry for drying pink pepper (Schinus terebinthifolius). Agricultural Engineering Internationa Journal, 12(1), 177-180.

Caires, S. M., Fontes, M. P. F., Fernandes, R. B. A., Neves, C. L., \& Fontes, R. L. F. (2011). Desenvolvimento de mudas de Cedro-rosa em solo contaminado com cobre: tolerância e potencial para fins de fitoestabilização do solo. Revista Árvore, 35(6), 1181-1188. https://doi.org/10.1590/S0100-67622011000700004

Caviglione, J. H., Kiihl, L. R. B., Caramori, P. H., \& Oliveira, D. (2001). Cartas climáticas do Paraná (p. 11). Londrina: IAPAR.

Desikan, R., Last, K., Harrett-Williams, R., Tagliavia, C., Harter, K., Hooley, R., ... Neill, S. J. (2006). Ethylene-induced stomatal closure in Arabidopsis occurs via AtrbohF-mediated hydrogen peroxide synthesis. The Plant Journal, 47, 907-916. https://doi.org/10.1111/j.1365-313X.2006.02842.x

Ferraz, R. L. S., Melo, A. S., Suassuna, J. F., Brito, M. E. B., Fernandes, P. D., \& Nunes Júnior, E. S. (2012). Trocas gasosas e eficiência fotossintética em ecótipos de feijoeiro cultivados no semiárido. Revista Pesquisa Tropical, 42, 181-188. https://doi.org/10.1590/S1983-40632012000200010

Gonçalves, E. O., Paiva, H. N. De., Neves, J. C. L., \& Gomes, J. M. (2012). Nutrição de mudas de angico-vermelho (Anadenanthera macrocarpa (Benth.) Brenan) submetidas a doses de N, P, K, Ca E Mg. Revista Árvore, 36(2), 219-228. https://doi.org/10.1590/S0100-67622012000200003

Haubrick, L. L., Torsethaugen, G., \& Assmann, S. M. (2006). Effect of brassinolide, alone and in concert with abscisic acid, on control of stomatal aperture and potassium currents of Vicia faba guard cell protoplasts. Physiologia Plantarum, 128, 134-143. https://doi.org/10.1111/j.1399-3054.2006.00708.x

Hayat, Q., Hayat, S., Irfan, M., \& Ahmad, A. (2010). Effect of exogenous salicylic acid under changing environment: a review. Environmental and Experimental Botany, 68(1), 14-25. https://doi.org/10.1016/j.en vexpbot.2009.08.005

Horváth, E., Szalai, G., \& Janda, T. (2007). Induction of abiotic stress tolerance by salicylic acid signaling. Journal of Plant Growth Regulation, 26(3), 290-300. https://doi.org/10.1007/s00344-007-9017-4

Jacobs, D. F., \& Landis, T. D. (2009). Nursery manual for native plants: Guide for tribal nurseries. Washington: Department of Agriculture, Forest Service.

Jadoski, S. O., Klar, A. E., \& Salvador, E. D. (2005). Relações hídricas e fisiológicas em plantas de pimentão ao longo de um dia. Ambiência, 1, 11-19.

Jaimez, R. E., Rada, F., García-Nunes, C., \& Azócar, A. (2005). Seasonal variations in leaf gas exchange of plantain cv. 'Hartón' (Musa AAB) under different soil water conditions in a humid tropical region. Scientia Horticulturae, 104(1), 79-89. https://doi.org/10.1016/j.scienta.2004.07.002

Kabiri, R., Farahdakhsh, H., \& Nasibi, F. (2012). Effect of drought stress and its interaction with salicylic acid on black cumin (Nigella sativa) germination and seedling growth. World Applied Sciences Journal, 18(4), 520-527. 
Kang, G., Li, G., \& Guo, T. (2014). Molecular mechanism of salicylic acid-induced abiotic stress tolerance in righer plants. Acta Physiologiae Plantarum, 36(9), 2287-2297. https://doi.org/10.1007/s11738-014-1603-z

Khan, N., Syeed, S., Masood, A., Nazar, R., \& Iqbal, N. (2010). Application of salicylic acid increases contents of nutrients and antioxidative metabolism in mungbean and alleviates adverse effects of salinity stress. International Journal of Plant Biology, 1(1), 1-8. https://doi.org/10.4081/pb.2010.e1

Khodary, S. E. A. (2004). Effect of salicylic acid on growth, photosynthesis and carbohydrate metabolism in salt stressed maize plants. International Journal of Agriculture and Biology, 6(1), 5-8.

Khokon, A. R., Okuma, E., Hossain, M. A., Munemasa, S., Uraji, M., Nakamura, Y., ... Murata, Y. (2011). Involvement of extracellular oxidative burst in salicylic acid-induced stomatal closure in Arabidopsis. Plant Cell Environ, 34(3), 434-443. https://doi.org/10.1111/j.1365-3040.2010.02253.x

Liu, X., Meng, F. X., Zhang, S. Q., \& Lou, C. H. (2003). $\mathrm{Ca}^{2+}$ is involved in the signal transduction during stomatal movement induced by salicylic acid in Vicia faba. Journal of Plant Physiology and Molecular Biology, 29(1), 59-64.

Lopez, F. B., Chauhan, Y. S., \& Johansen, C. (2008). Effects of timing of drought stress on leaf area development an canopy light interception of short-duration pigeonpea. Journal of Agronomy and Crop Science, 178(1), 1-7. https://doi.org/10.1111/j.1439-037X.1997.tb00344.X

Marenco, R. A., Antezana-Vera, S. A., Gouvêa, P. R. dos S., Camargo, M. A. B., Oliveira, M. F. de, \& Santos, J. K. da S. (2014). Fisiologia de espécies florestais da Amazônia: fotossíntese, respiração e relações hídricas. Revista Ceres, 61(1), 786-799. https://doi.org/10.1590/0034-737x201461000004

Mazzuchelli, E. H. L., Souza, G. M., \& Pacheco, A. C. (2014). Rustificação de mudas de eucalipto via aplicação de ácido salicílico. Pesquisa Agropecuária Tropical, 44(4), 443-450. https://doi.org/10.1590/S1983-406320 14000400012

Melotto M., Underwood W., Koczan J., Nomura K., \& He S. Y. (2006). Plant stomata function in innate immunity against bacterial invasion. Cell, 126(5), 969-980. https://doi.org/10.1016/j.cell.2006.06.054

Nivedithadevi, D., Somasundaram, R., \& Pannerselvam, R. (2012). Effect of abscisic acid, paclobutrazol and salicylic acid on the growth and pigment variation in Solanum Trilobatum. International Journal of Drug Development e Research, 4(3), 236-246.

Noriega, G., Caggiano, E., Lecube, M. L., Cruz, D. S., Batlle, A., Tomaro, M., \& Balestrasse, K. B. (2012). The role of salicylic acid in the prevention of oxidative stress elicited by cadmium in soybean plants. Biometals, 25(6), 1155-1165. https://doi.org/10.1007/s10534-012-9577-z

Nickerson, K., \& Flory S. L. (2015). Competitive and allelopathic effects of the invasive shrub Schinus terebinthifolius (Brazilian peppertree). Biological Invasions, 17(2), 555-564. https://doi.org/10.1007/s105 30-014-0748-4

Oliveira, M. A. J., Bovi, M. L. A., Machado, E. C., Gomes, M. M. de A., Habermann, G., \& Rodrigues, J. D. (2002). Fotossíntese, condutância estomática e transpiração em pupunheira sob deficiência hídrica. Scientia Agrícola, 59(1), 59-63. https://doi.org/10.1590/S0103-90162002000100008

Oliveira, A. D., Fernandes, E. J., \& Rodrigues, T. J. D. (2005). Condutância estomática como indicador de estresse hídrico em feijão. Engenharia Agrícola, 25, 86-95. https://doi.org/10.1590/S0100-69162005000 100010

Pál, M., Kovács, V., Szalai, G., Soós, V., Ma, X., Liu, H., ... Janda, T. (2014). Salicilic acid and abiotic stress responses in rice. Journal of Agronomy and Crop Science, 200(1), 1-11. https://doi.org/10.1111/jac.12037

Pereira, R. P. W., Abreu, H. S., Monteiro, M. B. O., \& Souza, N. D. (2011). Variação lignoanatômicaem mudas de Eucalyptus grandis (Hill ex Maiden) tratadas com reguladores decrescimento. Cerne, 17(3), 369-375. https://doi.org/10.1590/S0104-77602011000300011

Piccinelli, A. C., Santos, J. A., Konkiewitz, E. C., Oesterreich, S. A., Formagio, A. S., Croda, J., ... Kassuya, C. A. (2015). Antihyperalgesic and antidepressive actions of (R)-(+)-limonene, $\alpha$ - phellandrene, and essential oil from Schinus terebinthifolius fruits in a neuropathic pain model. Nutritional Neuroscience, 18(5), 217-224. https://doi.org/10.1179/1476830514Y.0000000119

Picolotto, L., Manica-Berto, R., Pazin, D., Pasa, M. da S. Schmitz, J. D., Prezotto, M. E., ... Fachinello, J. C. (2009). Características vegetativas, fenológicas e produtivas do pessegueiro cultivar Chimarrita enxertado em 
diferentes porta-enxertos. Pesquisa Agropecuária Brasileira, 44(6), 583-589. https://doi.org/10.1590/ S0100-204X2009000600006

Sakuragui, C. M., Stefano, M. V., \& Calazans, L. S. B. (2013). Meliaceae. Lista de Espécies da Flora do Brasil (p. 180). Rio de Janeiro: Jardim Botânico do Rio de Janeiro.

Santos, S. S., Moura, M. F., Guedes, R. S., \& Gonçalves, E. P. (2009). Emergência e vigor de plântulas de Cedrela fissilis L. em função de diferentes posições de profundidades de semeadura. Biotemas, 22(4), 45-52. https://doi.org/10.5007/2175-7925.2009v22n4p45

Scalon, S. de P. Q., Mussury, R. M., Euzébio, L. de M., Kodama, F. M., \& Kissmann, C. (2011). Estresse hídrico no metabolismo e crescimento inicial de mudas de mutambo (Guazuma ulmifolia Lam.). Ciência Florestal, 21(4), 655-662. https://doi.org/10.5902/198050984510

Singh, B., \& Usha, K. (2003). Salicylic acid induced physiological and biochemical changes in wheat seedlings under water stress. Plant Growth Regulation, 39(2), 137-141. https://doi.org/10.1007/s10725-007-9211-1

Taiz, L., \& Zeiger, E. (2017). Estresse abiótico. Fisiologia Vegetal (6th ed., Capter 24, pp. 731-759). Porto Alegre.

Tanaka, Y., Sano, T., Tamaoki, M., Nakajima, N., Kondo, N., \& Hasezawa, S. (2006). Cytokinin and auxin inhibit abscisic acid-induced stomatal closure by enhancing ethylene production in Arabidopsis. Journal of Experimental Botany, 57(10), 2259-2266. https://doi.org/10.1093/jxb/erj193

Zhang, Y., Xu, S., Yang, S., \& Chen, Y. (2015). Salicylic acid alleviates cadmium-induced inhibition of growth and photosynthesis through upregulating antioxidant defense system in two melon cultivars (Cucumis melo L.). Protoplasma, 252(3), 911-924. https://doi.org/10.1007/s00709-014-0732-y

\section{Copyrights}

Copyright for this article is retained by the author(s), with first publication rights granted to the journal.

This is an open-access article distributed under the terms and conditions of the Creative Commons Attribution license (http://creativecommons.org/licenses/by/4.0/). 